\title{
PEDOGEOGRAFSKE IN VEGETACIJSKOGEOGRAFSKE ZNAČILNOSTI JULIJSKIH ALP
}

\author{
Franc Lovrenčak*
}

Prispevek prikazuje prsti in vegetacijo kot sestavini gorske pokrajine v Julijskih Alpah na dveh zgledih, $v$ dolini Planice in na južni ter severni strani Bohinjskega jezera. Ta dva dejavnika sta prispevala $k$ oblikovanju značilnih naravnih enot. Te enote pa se zaradi različne lege in izoblikovanosti obeh predelov raztezajo v pasovih, ki v Planici potekajo od juga proti severu in ob Bohinjskem jezeru od vzhoda proti zahodu.

Ključne besede: prst, vegetacija, naravne enote, Planica, severna in južna stran Bohinjskega jezera

\author{
PEDOGEOGRAPHIC AND VEGETATIONAL GEOGRAPHIC CHARACTERISTICS \\ OF THE JULIAN ALPS
}

\section{Abstract}

The article shows soils and vegetation as elements of the alpine landscape of the Julian Alps by way of two examples - i.e. in the Planica valley as well as in the southern and northern part of the Bohinj lake. These two factors influenced the appearance of the typical natural units. These units, however - due to various positions and shapes - take the form of belts which in the Planica valley stretch from the south to the north and along the Bohinj lake from the west to east.

Key words: soil, vegetation, natural units, Planica, southern and northern part of the Bohinj lake

\footnotetext{
* Dr.,izr. univ. prof., Oddelek za geografijo, Filozofska fakulteta, Univerza v Ljubljani Aškerčeva 2, SI-1000 Ljubljana, Slovenija
} 


\section{UVOD}

Med pokrajinotvorne dejavnike v slovenskih Alpah sodita tudi prst in rastlinstvo. Obe ti dve sestavini pokrajine sta, $v$ težjem dostopnem gorskem svetu, ostali od še razmeroma nedotaknjeni. Zato je njuno dobro poznavanje eden od temeljev za pravilen in uspešen sonaravni razvoj tega dela Slovenije. Prsti in rastlinstvo sta tudi pomembna naravna vira in ju je treba tako tudi obravnavati, pravilno gospodariti $z$ njima in ju varovati (3). V prispevku so prikazane prsti in rastlinstvo kot sestavni del gorske pokrajine $\mathrm{v}$ Julijskih Alpah, na zgledih iz doline Planice in pojezerja Bohinjskega jezera. Obe območji sta primerjani s pojezerjem Blejskega jezera, pokrajino, ki je že na robu Julijskih Alp.

\section{PRSTI IN RASTLINSTVO V PLANICI}

Na lastnosti prsti in s tem tudi na sestavo ter na razširjenost rastlinstva v Planici so precej vplivali procesi preoblikovanja površja. Zlasti pomembno je bilo ledeniško oblikovanje doline $\mathrm{v}$ pleistocenu. Ledene gmote so izdelale široko U-dolino in odložile morenski grušč na njeno dno. Po ledeni dobi so eksogene sile preoblikovale dolino naprej. Iz pobočji nad dolino se je kotalil grušč in nastala so obsežna melišča, ki so ponekod že fosilna, drugod pa so še živa, saj še vedno nastajajo. Gams (1991) melišča deli na podstenska in podžlebna. Številni hudourniki so in še vedno nanašajo velike količine grušča. Tako je nastala cela vrsta vršajev, ki segajo bolj ali manj globoko v dolinsko dno. Na nekaj mestih med moreno, ki je v sredini doline, in vršaji, ki so na dolinskih bokih, pa se je usedlo drobnozrnato kaminsko gradivo, ki $\mathrm{mu}$ domačini pravijo kreda. $\mathrm{S}$ tem usedanjem so nastale majhne ravne ploskve, ki se dobro ločujejo od okoliškega razgibanega površja.

$\mathrm{Na}$ teh različnih reliefnih oblikah, ki jih sestavlja različna kamninska podlaga, so se $\mathrm{v}$ pedogenetskih procesih izoblikovale tudi različne prsti. Strma skalnata pobočja večinoma prekrivajo plitve rendzine, ki jih na položnejših delih porašča grmovno rastlinstvo slečnika in ruševja (Rhodothamno-Mugetum), na strmih delih pa nesklenjeno zeliščno rastlinstvo.

$\mathrm{Na}$ živih meliščih in vršajih še ni prsti, na fosilnih pa se je že začela tvoriti prst. Na velikih vršajih se kaže pet stopenj zaraščanja $\mathrm{z}$ rastlinami in tudi več stopenj $\mathrm{v}$ razvoju prsti. V prvi stopnji, po stopnji nič (živ grušč brez prsti in rastlinstva), nastaja litosol, globok 2-3 cm. Njegov profil gradi (A) horizont, ki se nahaja na horizontu C grušča. V zgornjem horizontu je malo (približno 1\%) slabo razpadle organske snovi. 
20-30\% tal poraščajo pionirske rastlinske vrste, npr. ščitasta kislica (Rumex scutatus), snežnobeli repuh (Petasites paradoxus) itn.

V drugi stopnji, ki jo označujemo kot stopnjo z alpsko veleso (Dryas octopetala), se pojavlja že več rastlin, ki poraščajo približno $50 \%$ tal. Značilna je alpska velesa, ki v obliki otočkov porašča tla. Z njo rastejo še snežnobeli repuh in nizki grmički ruševja (Pinus mugo). Gruščnato površje poraščajo tudi mahovi. Prst je plitva (do $3 \mathrm{~cm}$ globoka) in jo še vedno uvrščamo v tip litosola.

Za tretjo stopnjo je značilno nizko ruševje, ki že sklenjeno porašča tla. Na gosto se razrašča v grmovnem sloju in doseže višino od 2 do $3 \mathrm{~m}$. Z njim rasteta še žarkasta košeničica (Genista radiata) in dlakavi sleč (Rhododendron hirsutum). V zeliščnem sloju prevladuje spomladanska resa (Erica carnea). To rastlinstvo porašča že izoblikovano rendzino, ki sklenjeno prekriva matično podlago. Globoka je približno $10 \mathrm{~cm}$. Profil gradi horizont A, ki vsebuje črn humus. Pod njim je horizont $\mathrm{C}$ iz sivobelega grušča.

Četrta stopnja je stopnja z visokim ruševjem, ki 75-100 odstotno porašča tla. Grmi ruševja imajo do $5,5 \mathrm{~m}$ visoke veje. $Z$ njimi rastejo še navadni brin (Juniperus communis), žarkasta košeničica, dlakavi sleč in pritlikava jerebika (Sorbus chamaemespilus). V zeliščnem sloju se razraščajo trave, ki skoraj popolnoma poraščajo tla. Prst je rendzina, ki sega $10-15 \mathrm{~cm}$ globoko. Profil je sestavljen iz horizontov A-C.

V zadnji, t.j. peti stopnji, stopnji s smreko (Picea abies) in bukvijo (Fagus sylvatica) $\mathrm{z}$ ruševjem, pa se že kaže prehod $\mathrm{v}$ klimoconalo združbo alpskega bukovega gozda (Anemone-Fagetum). Na tej stopnji je že svetel gozd, kjer je zaradi obilice svetlobe dobro razvit grmovni in zeliščni sloj. Rastline rastejo na najgloblji $(22 \mathrm{~cm})$ in najbolj izoblikovani rendzini, v primerjavi s prejšnjimi stopnjami, ki jo gradijo horizonti AAC-C.

$\mathrm{Na}$ moreni v srednjem delu doline se je na vegastem površju izoblikovala rendzina $\mathrm{z}$ izrazitim organskim horizontom $\mathrm{O}$, ki ga sestavlja slabo razpadala organska snov. Porašča jo alpski bukov gozd, v katerem prevladuje bukev. Z njo se mešata še smreka in jelka (Abies alba). Na drobnozrnati usedlini (kredi) je v pedogenetskem procesu nastala najgloblja prst, ki sega $47 \mathrm{~cm}$ globoko. Njena sistematska pripadnost še ni jasna.

Po svojih fizikalnih in kemičnih lastnostih se ta prst razlikuje od sosednjih. To je vzrok, da na njej rastejo druge rastline kot v okolici. Uspevajo zlasti vrbe (Salix sp.) in zeliščne rastlinske vrste, ki na gosto poraščajo tla. Taka rastlinska sestava in gosta zaraščenost kažeta na večjo vlažnost v tleh (Lovrenčak, 1995). 


\section{PRSTI IN RASTLINSTVO V POJEZERJU BOHINJSKEGA JEZERA}

Pojezerje Bohinjskega jezera omejuje razvodnica voda, ki se stekajo v jezero. Poteka po robu strmih pobočij nad jezersko kotanjo: na jugu od Rjave skale proti zahodu okoli Žagarjevega grabna in Ražnove suhe, po robu Komne in Komarče preko Pršivca in po južnem robu planote, kjer so fužinarske planine, po robu Vogarja, od koder se spusti v dolino, prečka Savo Bohinjko in se zopet dvigne preko Velikega Gradu na visoki južni rob do Rjave skale. V pojezerju so na različnih reliefnih oblikah in različnih ekspozicijah nastale različne prsti, ki jih porašča različno rastlinstvo.

Tako kot v Planici je tudi v Bohinju ledeniško delovanje imelo močan vpliv na oblikovanje reliefa. Ledene gmote so prispevale k izoblikovanju strmih pobočij nad jezersko kotanjo. Obsežna melišča in vršaji pokrivajo vznožja pobočij zlasti na severni strani jezera in segajo marsikje prav do jezerske obale, tako da tu skoraj ni ravnega površja. Nad melišči pa se dvigajo strma, ponekod prepadna, gola skalnata pobočja. Na južni strani so pobočja pod Voglom bolj vstran od jezera, tako da je pri Naklem več ravnega površja.

$\mathrm{Na}$ preučevanem reliefnem profilu preko dela pojezerja Bohinjskega jezera $\mathrm{v}$ smeri jug-sever so nastale različne reliefne oblike. Njihova različnost in razlike v matični podlagi povzročajo razlike tudi v prsti in rastlinstvu (sl. 1). Razlikujemo lahko dve pokrajinsko ekološki enoti, ki se vsaka deli na dve podenoti.

1. Strma skalna pobočja. Na južni strani pojezereja pod Voglom in na njegovi severni strani pod Pršivcem se dvigajo strma (naklon približno $30^{\circ}$ ), ponekod prepadna pobočja iz triasnega apnenca in dolomita. Zaradi velike nagnjenosti so bili $\mathrm{v}$ erozijskem procesu delci prsti odnešeni in prsti sploh ni, tako da gleda na dan živa skala. Na položnejših delih pobočij se je ohranil plitev horizont prsti rendzine, ki omogoča rast rastlin. Taka prst se nahaja na že delno razpadli kaminski podlagi in na grušču, ki prekriva trdo kamninsko podlago. 
Slika 1: Prsti in rastlinstvo na prečnem prerezu med Voglom in Pršivcem.

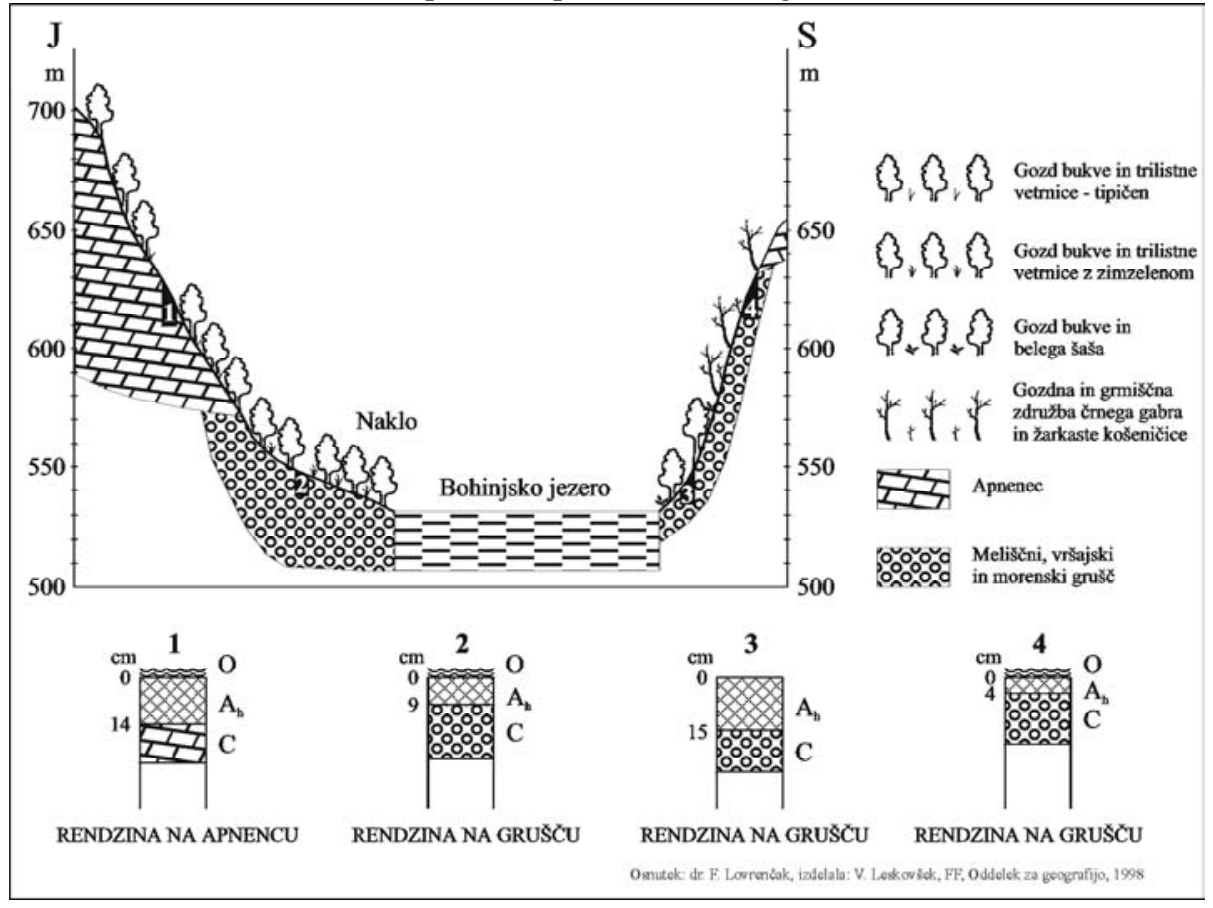

Na severni strani pod Pršivcem je na takem grušču rendzina globoka le $4 \mathrm{~cm}$ in ima zgradbo profila A-C. Nad horizontom A je približno $4 \mathrm{~cm}$ debel horizont $\mathrm{O}$, ki ga sestavlja bolj ali manj razpadlo listje dreves in grmov ter deli posušenih zeliščnih rastlinskih vrst. Prst je zelo skeletna. Po teksturi je zgornji horizont peščeno ilovnat, vsebuje več kot $70 \%$ delcev grobega in drobnega peska. V horizontu A je približno $12 \%$ prhninastega humusa. Delež kalcijevega karbonata $\mathrm{v}$ njem je precejšen (več kot $53 \%$ ), reakcija je nevtralna ( $\mathrm{pH} \vee \mathrm{KCl} 6,51)$ (tabela 1, profil 4). 
Tabela 1: Nekatere lastnosti prsti v pojezerju Bohinjskega jezera

\begin{tabular}{|c|c|c|c|c|c|c|c|c|c|c|}
\hline Profil & $\begin{array}{c}\text { Številka } \\
\text { vzorca }\end{array}$ & Horizont & $\%$ peska & $\%$ melja & $\%$ gline & Tekstura & $\begin{array}{c}\mathrm{pH} \mathrm{v} \\
0,1 \mathrm{KCl}\end{array}$ & $\begin{array}{c}\% \\
\mathrm{CaCO}_{3}\end{array}$ & $\begin{array}{c}\% \text { org. } \\
\text { snovi }\end{array}$ & $\begin{array}{c}\text { Globina } \\
\text { v cm }\end{array}$ \\
\hline & & & & & & & & & & \\
\hline 1 & 3 & $\mathrm{~A}_{\mathrm{h}}$ & 98,1 & 0,9 & 1 & $\mathrm{IP}$ & 6,06 & 0,94 & 30,63 & $0-14$ \\
\hline & 4 & $\mathrm{C}$ & & & & & & & & pod 14 \\
\hline 2 & 1 & $\mathrm{~A}_{\mathrm{h}}$ & 64,0 & 12,7 & 23,3 & PGI & 6,34 & 6,93 & 24,89 & $0-9$ \\
\hline & 2 & $\mathrm{C}$ & & & & & & & & pod 9 \\
\hline & & & & & & & & & & \\
\hline 3 & 13 & $\mathrm{~A}_{\mathrm{h}}$ & 57,9 & 15,4 & 26,7 & PGI & 6,68 & 3,98 & 14,04 & $0-15$ \\
\hline & 14 & $\mathrm{C}$ & & & & & & & & pod 15 \\
\hline & & & & & & & & & & \\
\hline 4 & 24 & $\mathrm{~A}_{\mathrm{h}}$ & 72,9 & 18,1 & 9 & PI & 6,51 & 53,28 & 12,45 & $0-4$ \\
\hline & 25 & $\mathrm{C}$ & & & & & & & & pod 4 \\
\hline
\end{tabular}

$\mathrm{IP}=$ ilovnati pesek, $\mathrm{PGI}=$ peščeno glinasta ilovica, $\mathrm{PI}=$ peščena ilovica

Glede na rastlinstvo to enoto ločujemo na dve podenoti: prva je na južni in druga na severni strani pojezerja. Na južni strani pod Voglom, ki je obrnjena proti severu, se v višjih in strmejših pobočjih razrašča alpski bukov gozd, združba bukve in trilistne vetrnice (Anemone -Fagetum typicum) (1). Med drevesnimi vrstami prevladuje bukev, z njo pa se meša smreka. Podrast je razmeroma redka, v grmovnem sloju so mladice bukve, v zeliščnem pa rastejo trilistna vetrnica (Anemone trifolia), jetrnik (Hepatica nobilis), deveterolistna konopica (Dentaria enneaphyllos) itn.

Prst v tej podenoti ima različno globino in zgradbo profila. Na strmejših delih pobočij se je izoblikovala plitva rendzina $(14 \mathrm{~cm}) \mathrm{s}$ profilom A-C. V horizontu A je približno $10 \%$ skeletnih delcev, po teksturi pa je ilovnati pesek z več kot $80 \%$ drobnega peska. Reakcija v tem horizontu je slabo kisla, delež kalcijevega karbonata pa ne dosega enega odstotka. Zgornji horizont je zelo humozen, saj delež humusa presega $30 \%$ (tabela 1, profil 1).

Na položnih, poličastih delih pobočja se je v pedogenezi izoblikoval globlji $(26 \mathrm{~cm})$ evtrični kambisol. Profil te prsti gradijo horizonti O-A-(B)-C. Organski horizont O je debel približno $10 \mathrm{~cm}$. Pod njim se nahaja temen, humozen (več kot $24 \%$ humusa) horizont A. Podobno kot pri rendzini ta horizont vsebuje veliko drobnega peska, tako da je njegova tekstura tudi ilovnati pesek. Podobna je tudi reakcija in delež kalcijevega karbonata.

Pod njim se nahaja rjav horizont (B), ki vsebuje izrazito več glinastih delcev in precej manj peščenih delcev kot zgornji horizont. Po teksturi sodi med ilovnate gline. Reakcija je slabo kisla, delež kalcijevega karbonata pa je večji kot v horizontu A. 
Vsebuje precej humusa, kar bi lahko razložili s plitvim $(12 \mathrm{~cm})$ horizontom A nad njim.

Severna stran pod Pršivcem je obrnjena proti jugu. Zato je tu toplo in sončno rastišče s suho prstjo. Vse to je povzročilo na strmih skalnatih pobočjih, delno prekritih s preperinskim gruščem, drugačne rastne razmere kot na južni strani pojezerja. Po pobočjih nad pasom melišč se razrašča drugačno rastlinstvo kot na južni strani. Tu je M. Wraber (1961) opisal termofilno drevesno-grmovno združbo gabrovca in omelike (črnega gabra in žarkaste košeničice) ${ }^{*}$ (Cytisantho radiati-Ostryetum). V drevesnem sloju rastejo črni gaber (Ostrya carpinifolia), mali jesen (Fraxinus ornus) in mokovec (Sorbus aria).V grmovnem sloju rastejo poleg naštetih drevesnih vrst še nizki grmi: žarkasta košeničica (Genista radiata), ruj (Cotinus coggyria), šmarna hrušica (Amelanciher ovalis) itn. V zeliščnem sloju rastejo mnoge vrste: pisana šaušulica (Calamgrostis varia), navadna glota (Brachypodium pinnatum), krvavo rdeča krvomočnica (Geranium sangunieum), spomladanska resa (Erica carnea) in mnoge druge.

2. Melišča in vršaji. Melišča so ena najbolj značilnih oblik površja na severni strani Bohinjskega jezera pod strmimi skalnatimi stenami, kjer marsikje, zlasti na severozahodni strani, segajo do jezerske obale. Sestavlja jih grušč, ki ponekod sega v jezero. Bolj proti severovzhodu so melišča odmaknjena od jezerske obale in je več položnega površja. Podobno je na južni strani, kjer so hudourniki nasuli grušč in z vršaji ustvarili več planega površja, npr. Naklo. Tu in še vzdolž te južne strani so bili odloženi tudi ledeniški nanosi (2).

$\mathrm{Na}$ grušču fosilnih melišč in vršajev ter na nesprijetem grušču morene se je že izoblikovala plitva rendzina, globoka približno $10 \mathrm{~cm}$. Nad horizontom A je organski horizont $\mathrm{O}$ odpadlega, večinoma bukovega listja, debel približno $5 \mathrm{~cm}$. Horizont pod njim je temnorjav (7,5 YR 3/3). Med kamninskimi delci prevladujejo peščeni, grobega in drobnega peska je več kot $60 \%$, zato je tekstura peščeno glinasto ilovnata. $\mathrm{V}$ horizontu A se nahaja tudi precej skeletnih delcev (30-40\%). Reakcija je v tem horizontu slabo kisla do nevtralna ( $\mathrm{pH}$ 6,34-6,5), delež kalcijevega karbonata je več kot $6 \%$. Delež organskih snovi je precejšen (več kot $24 \%$ ). Te lastnosti rendzine kažejo na še razmeroma mlado prst, saj nastaja na mladi gruščnati matični podlagi (tabela 1, profil 2).

Tudi to drugo enoto po rastlinstvu ločujemo na dve podenoti. Prva je na južni in druga na severni strani pojezerja. Na južni strani v nižji nadmorski višini do približno $600 \mathrm{~m}$ se razprostira bukov gozd, ki pripada podzdružbi bukve in trilistne vetrnice $\mathrm{z}$ malim zimzelenom (Anemone - Fagetum vincetosum). V drevesnem sloju izrazito

\footnotetext{
* Gabrovec sin. črni gaber (Ostrya carpinifolia), omelika [Cytisanthus radiatus (L.) Lang.] sin. žarkasta košeničica [Genista radiata (L.) Scop.]
} 
prevladuje bukev, z njo se redko meša smreka. V grmovnem sloju raste le malo grmov, podmladek bukve, leska (Corylus avellana) itn. Bolj bogat je zeliščni sloj, kjer se ponekod močno razrašča mali zimzelen (Vinca minor). Z njim rastejo še trilistna vetrnica, jetrnik, dvolistna senčnica (Maianthemum bifolium), črni teloh (Helleborus niger) itn. Ta podzdružba porašča skoraj ves nižji in položnejši južni del pojezerja, kjer je hladno in vlažno, od pod Velikega Gradu do Ukanca.

Za drugo podenoto na severni strani pojezerja $\mathrm{v}$ nižji nadmorski višini je značilno položnejše površje, plitva rendzina (globina $15 \mathrm{~cm}$ ) na grušču (tabela 1, profil 3) in zaradi prisojnega toplega ter suhega rastišča gozdna združba belega šaša in bukve (Carici albae - Fagetum). Tudi v tem gozdu prevladuje bukev, z njo pa se meša smreka. Ta gozd so deloma posekali in na njegovem rastišču uredili pašnike. Vendar se na njih že razraščajo grmi navadnega brina, navadne leske itn., kar kaže, da se pase manj živine.

\section{SKLEPI}

Primerjava prsti in rastlinstva v Planici in ožjem delu pojezerja Bohinjskega jezera pokaže nekaj podobnosti in določene razlike. V obeh delih Julijskih Alp so V pedogenezi na mladi matični podlagi, t.j. na grušču (melišč, vršajev), nastali litosoli s profilom (A)-C, na starejšem grušču (tudi morenskem) pa že bolj razvite prsti, ki jih uvrščamo k rendzinam. Njihov profil, ki je večinoma globok do $20 \mathrm{~cm}$, gradijo horizonti A-C ali A-AC-C. V gozdu se nad horizontom A nahaja še organski horizont O. Horizont A je večinoma temnorjave barve, precej humozen, ponekod skeleten in večinoma $\mathrm{z}$ večjim deležem peska. Reakcija $\mathrm{v}$ tem horizontu je slabo kisla do nevtralna.

Precejšne razlike pa se kažejo zlasti v rastlinstvu. Te razlike povzročajo podnebne razmere, ki izvirajo iz razlik v legi obeh delov Julijskih Alp. Dolina Planice večinoma poteka v smeri jug-sever, pojezerje Bohinjskega jezera pa ravno nasprotno, vzhodzahod. Zato se tu kaže izrazita razlika med prisojno in osojno stranjo, v Planici pa tega ni. Na prisojni strani pojezerja se razrašča toploljubna vegetacija črnega gabra in žarkaste košeničice, na osojni pa alpski bukov gozd. Ta gozd na široko porašča tudi osrednje dele doline in delno spodnja pobočja $\mathrm{v}$ Planici, melišča in vršaji pa so $\mathrm{v}$ različnih stopnjah zaraščanja $\mathrm{z}$ grmovnim in zeliščnim rastlinstvom.

Lega in izoblikovanost obeh predelov je povzročila tudi različen potek njihovih pokrajinsko ekoloških enot, ki se raztezajo v pasovih. V Planici ti potekajo od juga proti severu, v pojezerju pa od vzhoda proti zahodu. V dolini Planice je mogoče razločevati štiri take enote, za katere je značilna oblika reliefa, matična podlaga, prst 
in vegetacija. Te enote so: skalnata pobočja na vzhodni, zahodni in južni strani doline, melišča in vršaji, morena in kotanje s kredo. $\mathrm{V}$ ožjem delu pojezerja pa sta dve enoti: skalnata pobočja na južni in severni strani ter melišča in vršaji na južni in severni strani. Obe enoti imata vsaka po dve podenoti, ki se razlikujeta glede na razlike $\mathrm{v}$ mezoklimi na obeh straneh Bohinjskega jezera prav po rastlinstvu.

Potek in razprostranjenost pokrajinskih enot v pojezerju Blejskega jezera v primerjavi s Planico in pojezerjem Bohinjskega jezera ne kažeta izrazite pasovitosti, saj je tu relief bolj razgiban. Pomembno je tudi to, da je blejsko pojezerje že del Ljubljanske kotline in se odpira na vzhod v kotlino. Za njegovo površje je značilno menjavanje dvignjenih osamelcev in nižjih, ravnih ploskev, kar povzroča razprostiranje pokrajinskih enot bolj v obliki otokov kot pasov.

\section{LITERATURA IN VIRI}

1. Alpska konvencija v Sloveniji. Ministrstvo za okolje in prostor. Ljubljana 1997.

2. Buser S., Osnovna geološka karta SFRJ Tolmin in Videm 1:100 000. Beograd 1986.

3. Gams I., 1991: Dvojno življenje melišč. Proteus 53-8. Ljubljana.

4. Kamp Ukanc v Bohinju. Ocena vplivov na okolje in variantni predlogi za dolgoročno reševanje problemov obalnega območja Bohinjskega jezera. Gozdarski inštitut Slovenije. Ljubljana 1995.

5. Lovrenčak F., 1995: Zveze med reliefom, prstmi in vegetacijo v Planici. Geografski vestnik 67. Ljubljana.

6. Melik A., 1954: Slovenski alpski svet. Ljubljana.

7. Šnuderl K., 1998: Strokovne podlage za zasnovo celovitega koncepta razvoja okolice Bohinjskega jezera (diplomsko delo na Oddelku za geografijo Filozofske fakultete v Ljubljani). Ljubljana.

8. Wraber M., 1961: Termofilna združba gabrovca in omelike v Bohinju. Razprave VI SAZU. Ljubljana. 


\title{
PEDOGEOGRAPHIC AND VEGETATIONAL GEOGRAPHIC CHARACTERISTICS OF THE JULIAN ALPS
}

\begin{abstract}
Summary
A comparison between the soils and plants in the Planica valley and in the central part of the Bohinj lake yields some similarities and certain differences. Lithosols with an (A)-C profile came into being on the parent material of later date i.e. on gravel (screes, alluvial cones) in the process of pedogenesis in both parts of the Julian Alps. More developed soils, which we classify as rendzinas, can be found on gravel of earlier date (also on moraine gravel). Their profile, mainly up to $20 \mathrm{~cm}$ deep, is composed of A-C or A-AC-C horizons. In the forest, the organic $\mathrm{O}$ horizon additionally developed above the A horizon. The A horizon is predominantly dark brown, it contains a lot of humus, at times sand particles. It often contains a large amount of sand. In this horizon $\mathrm{pH}$ is near 7.
\end{abstract}

Substantial differences occur with regard to vegetation. These differences are brought about by climatic conditions which are a result of various altitudes of both parts of the Julian Alps. The large part of the Planica valley lies in the direction south-north; the Bohinj lake area, however, in the direction east-west. Consequently, there is a striking difference between the sunny and shady side, while this is not the case in the Planica valley. Thermophilic vegetation of Ostrya carpinifolia and Genista radiata thrives on the sunny side of the lake, while the alpine beech forest (Anemone-Fagetum) thrives on the shady side. This forest covers large surfaces in the central part of the valley and partly the lower slopes of the Planica valley. Scrubs and herb vegetation have reached various stages of overgrowing on screes and alluvial cones.

Position and shape of the Planica valley and the Bohinj lake area caused a different development of their landscape-ecological units, which stretch in the form of stripes. In the Planica valley these stripes lie in the direction south north, as opposed to the lake region where they lie in the east-west direction. Four of such units can be distinguished in the Planica valley, which have a distinct form of relief, parent material, soil and vegetation. These units are:

1. rocky slopes on the eastern, western and southern valley sides

2. screes and alluvial cones

3. moraine

4. depressions with fine-grain sediments.

The central part of the lake can be divided into two units:

5. rocky slopes on the southern and northern sides

6. screes and alluvial cones on the southern and northern sides.

7. Each of the units has two sub-units, which differ with regard to vegetation as a consequence of changes in the mesoclimate on both sides of the Bohinj Lake. 
Position and vastness of landscape units in the Bled lake area do not show an obvious stripe-structure compared to the Planica valley and the Bohinj lake area, since the relief is characterised by more variety. The fact that the Bled lake area already constitutes a part of the Ljubljana basin, passing into a basin in the east, plays an important role. The interchange of isolated hills and lower, flat surfaces is characteristic of the landscape. The landscape units therefore assume the form of islands rather than stripes. 